\title{
Be green and you are branded: Case of Small to Medium Enterprises in Zimbabwe Tourism Sector
}

\author{
Farai Chigora \\ Lecturer at Catholic University of Zimbabwe \\ Email:fchigora@yahoo.com
}

Tel: +263772886871

Promise Zvavahera (Corresponding Author)

National University of Science and Technology, Zimbabwe

Email:promisezvavahera59@gmail.com

Tel: +263773471 703/2634706515

Doi:10.5296/ jebi.v2i2.7963 URL: http://dx.doi.org/10.5296/ jebi.v2i2.7963

\begin{abstract}
This study explored the effect of green management in sustainable development in the branding of Small to Medium Enterprises (SMEs) in the tourism sector in Zimbabwe. The study focused on businesses in the accommodation, travel and resorts areas of the tourism industry in Zimbabwe. The study used both quantitative and qualitative research design whereby data was extracted from the respondents using questionnaires and in-depth interviews. The key respondents to the study were managers and employees in the accommodation, travel sectors. The results of the study showed that SMEs in the Zimbabwean tourism industry do not appreciate the impact of green management as a branding tool. The findings indicated that most of the respondents were not aware on what of what green management is all about. A few managers appreciated the concept and concurred that green management in deed was being practised by large corporations the world over. It was concluded that having green and eco-labels displayed on business premises, letterheads and other business exchange would improve their branding and identity to the world. The study recommended that the operators in the accommodation, travel and resorts should adopt green and eco-certification programs so as to attract the modern enlightened tourist who is green and eco-sensitive.
\end{abstract}

Keywords: Small to Medium Enterprises (SMEs), Branding, Tourism, Green Management 


\section{Background of the study}

The development of SMEs is increasingly becoming popular in Zimbabwe. These business structures have been seen in various sectors though still at a low level of development in the tourism industry. Government of Zimbabwe has greatly supported the evolution of SMES, through establishing the Ministry of Small to Medium Enterprises and the relevant supporting policies. The Zimbabwe Agenda for Sustainable Socio-Economic Transformation (ZIMASSET) which is the current economic development plan is promoting the development of SMEs showing their high level of importance to government planning for economic growth. The tourism industry in Zimbabwe has been affected by various negative socio-economic and political events that destroyed the country's image as a safe tourism destination. Various economic policies including growth with equity (1981), First Five-Year National Development Plan (1986-1990), Economic Structural Adjustment Program (ESAP) (1991-1996), Zimbabwe Programme for Economic and Social Transformation (ZIMPREST) (1996-2000) and Short-Term Economic Recovery Programme (STERP I) (2010-2012) (ANSA et al, 2012) are some of the economic policies implemented but still the country is suffering from more intense negative publicity and poor performance of the economy.

The marketing of the tourism industry has also seen an effort by the government when it established the Zimbabwe Tourism Development Board (ZTD) in 1981 which was then transformed into the Zimbabwe Tourism Authority (ZTA) in 1996. The organisation became the dominating Destination Marketing Organisation (DMO) in Zimbabwe. In an effort to improve the negative perception and downfall of the tourism industry ZTA has initiated the branding of Zimbabwe as an attractive tourism destination to its source markets. After independence in 1980, the organisation launched the "Discover Zimbabwe" brand which received attraction to its source markets. The brand became ineffective in the decade around 1990 as reported that it did not consider critical stakeholders' contribution in its implementation. The country then rebranded to "Africa Paradise" in 1996 which was then massively followed by negative socio-economic and political events. These include the 2000 land reform, 2002 and 2008 presidential elections, rerun, persistent cholera epidemic and imposed sanctions by the European Union. These events resulted in negative publicity of the Zimbabwean tourism destination as an unsafe destination for visits and businesses. It crippled the economy with increased negative perception of the tourism industry to its former traditional source markets. The destination could not carry the paradise state it preached to the world. This then gave a new drive to maximize on the natural resources endowed by the country in order to create a new identity to the world. The ZTA then rebranded to "Zimbabwe and World of Wonders" in 2011. These are the signs of how policy makers are trying to revamp the tourism sector through branding.

However, the development of SMEs in the Zimbabwean tourism sector is a strategy to rejuvenate the glamour of big tourism industry that has failed to survive negative publicity. The SMEs however lack business knowledge in terms of the expertise that is needed to enhance operations. The challenges face by these SMEs include unavailability of resource (including financial, human and time), lack of knowledge and no interest of environment management (a/l Yacob \& Moorthy, 2012, p. 105). Mainly they lack marketing knowledge 
among other key business aspects. It is therefore hard for them to brand and rebrand their businesses.

There is a growth in sustainable development phenomenon in other economies (especially in the developed world) and has been appreciated and attracted attention of customers. Growing concerns about the environmental sustainability means that the economy and environment can no longer be considered in isolation (BOLOGNA+10, 2010, p. 4). Green management in tourism aligns with persistent government demand to improve natural environment performance in relation to individual enterprises gains (Furqan, Mat Som, \& Hussin, 2010, p. 64). In line with this, being certified for green practices provide a competitive advantage in niche markets as the destination will improve its credibility especially when there are existing threats on sustainable resource management (Batta, 2009). This is the use of green management resources as a way to survive in the current generation and benefiting the future. Nowadays consumers are more environmental friendly and would want to associate with organisations that are environmental friendly. The greenness of a product or service is simply derived from its ability to satisfy both the producer and consumer exerting minimum pressure to the environment (Furqan, Mat Som, \& Hussin, 2010, p. 65).Green management and labelling has become a key concept for identity and help in the branding of tourism businesses. Little practice of the green concepts has been realised in most developing countries.

\section{Literature}

Green certification has been widely practised around the globe especially in developed countries (Zengeni, Zengeni, \& Muzambi, 2013, p. 64). However, green management of resources is still at its infancy in the developing countries. The subject has been highly explored in the tourism sector in different countries with the aim of promoting sustainable business practices for all stakeholders. The practice of green management in tourism equates the effort by tourism establishments in providing a harmony with the environment and tourists who are also environmentally friendly (Furqan, Mat Som, \& Hussin, 2010, p. 64). In the tourism market place, the green management strategy gives companies a differential advantage over their competitors (Furqan, Mat Som, \& Hussin, 2010, p. 66). Also customer satisfaction is affected by environmental practices in the future (Gadenne, Kennedy, \& McKeiver, 2009, p. 47). Since tourism has been regarded as a vital contributor to economic development for many countries around the world (Graci \& Kuehnel, 2009, p. 1) sustainable practices should be applied for continual profits and growth. This is because receipts from tourism make an important contribution to the economies of the developing countries in terms of income employment, and balance of payments effects (Furqan, Mat Som, \& Hussin, 2010, p. 65).However, like any other sector in both developing and developed nations, business models and structures for the tourism industry are being redesigned to suite the prevailing socio-economic challenges. These challenges include liquidity crisis, global crunch, global warming and increased change in consumer tastes and preferences. The realised effect in current economies is closure of big businesses, retrenchments, high unemployment rate, increased global warming and a new sensitive customer who is eco-informed. This has seen various sectors reducing their business size and capacity so as to 
focus on a new structure which operates at a much smaller scale than before. This is the evolution of Small to Medium Business enterprises (SMEs). This type of business structure is increasing popularity across the globe and at an increased pace in Zimbabwe. SMEs are increasingly dominating the tourism sector world over and Zimbabwe in particular. They are coming as a business survival strategy so as to curb the socio-economic problems associated with economic downturn.

Through its massive growth the tourism industry has imposed more stress on the environment (Zengeni, Zengeni, \& Muzambi, 2013, p. 64). SMEs effect on the environment is increasing becoming a concern (a/l Yacob \& Moorthy, 2012, p. 104). This is emanates from the fact that the focus made on economic gains from tourism has ignored the desire to maintain the well-being of environments and socio-cultural (Furqan, Mat Som, \& Hussin, 2010, p. 65). Appreciation of the role placed by natural resources in tourism and economic development has led to both private and public players resorting to sustainable measures so as to counter any associated negative impacts (Furqan, Mat Som, \& Hussin, 2010, p. 66).

Tourism organisations that are practicing sustainable measures in their processes have managed to get profitable attention from both internal and external customers. Environment management has been used as an effective tool for differentiation and improving market share(Porter and van der Linde, 1995). Therefore the competitiveness of various operators has been attributed to ecological responsiveness (Bansal and Roth, 2000). Also customers have shown their interest in environment management becoming a source for information to do with environments(Williamson and Lynch-Wood, 2001). They are the groups most likely to convince business owners of the economic impact of environmental-friendly practices. This greatly mean that the impact of owners/managers perception and attitude towards green concept are important, as the environmental awareness of consumers caused them to seek for environmental friendly products ( $\mathrm{a} / \mathrm{l}$ Yacob \& Moorthy, 2012, p. 104). Therefore, green management may be used a new form of branding in the tourism sector with a particular focus on the developing and upcoming SMEs.

\subsection{Tourism SMEs and green practice}

Some small- and medium-sized enterprises (SMEs) have been climbing onboard the sustainability bandwagon due to increasing stakeholder pressures (Cordano, Murray, \& Marshall, 2010). SMEs are of particular significance as their degradation on environment is huge (a/l Yacob \& Moorthy, 2012, p. 103). The transition towards the green growth economy is highly demanding in SMEs, as they account for a large part of the world's consumption of resources and generation of waste (BOLOGNA+10, 2010, p. 3)

It is clear that SMEs around the world have little knowledge about environmental management and do not understand the concept of environmental management ( $\mathrm{a} / \mathrm{l}$ Yacob \&Moorthy, 2012, p. 104)The tourism industry has been pursuing green practices since the 1990s due to fluctuating economic levels and a strong focus on customer service (Claver-Cortes et al., 2007). Majority of SME managers in their study considered environmental responsibility and improvement as a financial cost (Gadenne, Kennedy, \& McKeiver, 2009, p. 47). 
Therefore SME owners may be influenced to engage in environmental friendly practices by a range of people including consumers, customers, local community groups, environmental groups, suppliers and investors from financial institutions (Gadenne, Kennedy, \& McKeiver, 2009, p. 47) .It has been argued that improvements in environmental management practices can result in a multitude of benefits to SMEs including reduction in waste, cost savings, increased customer satisfaction, higher employee commitment, improved products, better public relations and competitive advantage (Simpson et al., 2004). Empirical tests have shown a correlation between the environmental effort of the managers of SMEs and organizational operating efficiency, profits and business image (Naffziger et al., 2003). The biggest reported benefit for SMEs from green certification is cost savings through waste minimisation (Perry, 2001). Therefore, the benefits of green management to SME business include gaining competitive advantage by being a leader in the sector, Customer loyalty, Employee retention; Awards and recognition, Regulatory compliance, Risk management and Increased brand value (Graci \& Kuehnel, 2009). SMEs can use voluntary sustainability codes can go green (Cordano, Murray, \& Marshall, 2010). To a greater extent, highly creative and innovative SMEs in the service industry, contribute increasingly to eco-innovation and can sustain diffused transformation across a broad range of industries (BOLOGNA+10, 2010, p. 3).

Positive attitude of owners/managers towards the environment do not appear to be reflected in their actual business practices (a/l Yacob \& Moorthy, 2012, p. 105). However, in spite of generic awareness about the costs-benefits of eco-efficient practices, SMEs and entrepreneurs are little aware of the scale of the change to come and the full business benefits of eco-efficiency and sustainability (BOLOGNA+10, 2010, p. 6). In addition, most SMEs have little awareness about the future needs for new green skills and their investments in green training and knowledge-intensive activities are very limited (BOLOGNA+10, 2010, p. 8)

\subsection{Green tourism}

Green relates to environment friendly (Shrum, 2005).Green concept can be simplified in practise though difficult to define (Furqan, Mat Som, \& Hussin, 2010, p. 65). Green growth is about balancing and enhancing effective environment management and economic benefits with a further investment in sustainable environments(BOLOGNA+10, 2010, p. 2). The green practice has been seen in tourism industry though limited in transport and land activities (Furqan, Mat Som, \& Hussin, 2010, p. 65). The limitation in other areas resulted in green tourism especially in hotels and lodges (Zengeni, Zengeni, \& Muzambi, 2013, p. 64). The process of green management mainly focuses on reducing pollution, energy consumption, recycling, use of local products and savings(Graci \& Kuehnel, 2009, p. 3). Green tourism certification can help developing nations in adhering to environmentally friendly practises (Erdogan and Tosun, 2009). It is a vital concept in conserving and maintaining natural and cultural resources (Furqan, Mat Som, \& Hussin, 2010, p. 66). Establishments that have engaged green tourism have widened their opportunity to achieve a competitive advantage (Graci \& Kuehnel, 2009, p. 5). Therefore, green tourism is a holistic approach that enhance welfare of people, balance of natural resources, culture, meaningful participation and sustainable resource practices

(Furqan, Mat Som, \& Hussin, 2010, p. 66). According to 
Middleton and Hawkins (1998), various instruments have been used as green tourism certification identity such as logos and symbols (Furqan, Mat Som, \& Hussin, 2010, p. 66).

\subsection{Green Certification}

The certification is a voluntary process accompanied with setting of best practice standards that are followed by regular audits and assessment which will then receive accreditation in the form of awarded logos from regulating bodies (Furqan, Mat Som, \& Hussin, 2010, p. 67). Logos are therefore awarded to successful applicants only as an indication of recognition given (Honey and Rome, 2000).Certification helps in creating awareness of sustainable practices to business operators. Inform tourist on the social and environmental impact of tourism such that they become respectful and even contribute to related solutions (Batta, 2009). Certification impose standards that are used to distinguish those responsible from non-conforming ones and helps enhance market integrity (Furqan, Mat Som, \& Hussin, 2010, p. 69).SMEs may get certified with the ISO14000 to improve their reputation for good practice (Gadenne, Kennedy, \& McKeiver, 2009, p. 47).

\subsection{Tourism Branding and green management}

New brands including Starwood Capital's "1"Hotel and Residences, Starwood Hotel and Resorts Element and Hyatt's Andaz, which feature LEED certified buildings as part of their brand standards, offer a variety of green products, such as green spas and restaurants making them popular (Graci \& Kuehnel, 2009, p. 5). Green awards and recognition spread the news of the hotel's efforts and attracts new clientele, such as corporations that need to conduct business with socially responsible companies (Graci \& Kuehnel, 2009, p. 5).Employees as internal customers are increasingly sophisticated and "tuned" into current thinking in society and are far more likely to identify with an employer whose principles and practices are aligned with their values(Graci \& Kuehnel, 2009, p. 5). Employee turnover rate in the hotel sector is relatively high therefore increasing the retention rate will also save the business money in training of new staff (Graci \& Kuehnel, 2009, p. 5). Companies that integrate the environment into their business decisions and reduce their environmental risk and potential liabilities are in a better position to improve reputational market exposure (Graci and Dodds, 2009). The typical hotel guest of today is more sophisticated and to varying degrees is likely to be concerned about environmental issues such as recycling bottles, cans and paper at home as well as making greener lifestyle choices, such as organic food or fuel-efficient vehicles (Graci \& Kuehnel, 2009, p. 5).customer loyalty may increase once they have experienced a tourism establishment which has demonstrated a level of environmental commitment (Graci \& Kuehnel, 2009, p. 6).

\section{Problem Statement}

SMEs operating in the Zimbabwe tourism sector have not invested in brand management over the years. This has resulted in their failure to grow and improve capacity. Also it has destroyed their attractiveness as responsible brands on the global tourism market thus losing their competitiveness. Green management has emanated as a responsible conservation concept and has seen amalgamated efforts of business operators and environmentally friendly 


\section{Macrothink}

customers to spearhead on sustainable management of natural resources. Those who have used green tourism certification for identity have managed to position themselves as prime brands. The study therefore investigated the acceptance and practise of green environment management by SMEs in Zimbabwe tourism sector.

\section{Research Objectives}

The specific objectives of the study were to:

- Establish the relationship between branding of SMEs in the Zimbabwe tourism sector and green management.

- Assess the effects of branding to SMEs in the Zimbabwe tourism sector.

- Determine the effect green management to image building for SMEs in the Zimbabwe tourism sector.

- Establish sustainable environmental practices used by SMEs in the Zimbabwean tourism sector.

- Recommend on the impact of green management and branding to the image of SMEs in the Zimbabwe tourism sector.

\subsection{Research Questions}

- What is the relationship between branding of SMEs in the Zimbabwe tourism sector and green management?

- How does branding affect the business of SMEs in the Zimbabwe tourism sector?

- What is the effect of green management to the image of SMEs in the Zimbabwe tourism sector?

- Which sustainable environmental practices are being used by SMEs in the Zimbabwe tourism sectors?

- What recommendations are there for SMEs in Zimbabwe tourism sector on green management and branding as a tool for image building? 


\subsection{Conceptual Framework}

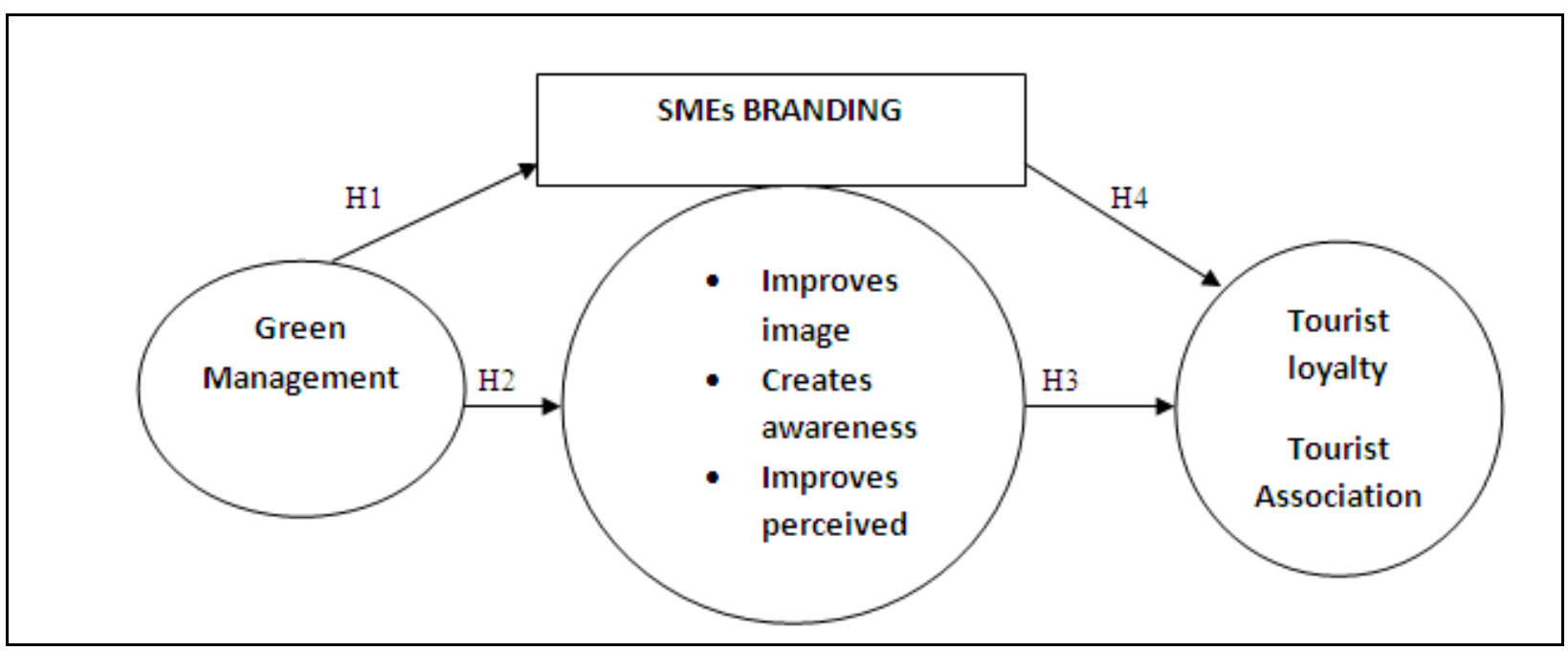

\section{Figure1.1 Research conceptual framework}

Source: Own Design

\section{Methodology}

The research paradigm was both post positivist and interpretivist. It therefore used both deductive and inductive means of collecting and analysing research data. The research design used for the study was a sequential mixed method starting with a qualitative research then validated by a quantitative research. In-depth interviews were done with senior managers from the accommodation, travel and resorts as a way to obtain qualitative data. Questionnaires were then distributed to managers and employees in the same sectors with the aim to get quantitative data. Stratified random sampling was used to obtain the sectors from the tourism industry from which research data extracted. The population for the study was 15 managers from the three sectors, 20 employees in accommodation, 35 employees from the travel sector and 45 in holiday resorts making a total of 115 respondents. 


\section{Macrothink

\section{Findings}

Table 1.1 Responses from major research questions (employees)

\begin{tabular}{|c|c|c|c|}
\hline \multirow[t]{2}{*}{ QUESTIONS } & \multicolumn{3}{|c|}{ \% RESPONSES } \\
\hline & Yes & No & $\begin{array}{l}\text { Not } \\
\text { Known }\end{array}$ \\
\hline $\begin{array}{l}\text { 1. Are you applying the green tourism concept in your } \\
\text { operations? }\end{array}$ & $15 \%$ & $85 \%$ & $0 \%$ \\
\hline $\begin{array}{l}\text { 2. Does green management of environment result in } \\
\text { brand awareness }\end{array}$ & $5 \%$ & $20 \%$ & $75 \%$ \\
\hline 3. Can green tourism improve brand identity? & $20 \%$ & $35 \%$ & $45 \%$ \\
\hline $\begin{array}{l}\text { 4. Does green management lead to improved perceived } \\
\text { quality in a destination? }\end{array}$ & $47 \%$ & $13 \%$ & $40 \%$ \\
\hline $\begin{array}{l}\text { 5. Is there a positive relationship between green tourism } \\
\text { and brand loyalty? }\end{array}$ & $5 \%$ & $10 \%$ & $85 \%$ \\
\hline
\end{tabular}

Source: Research Survey (2015)

Eighty five percent of the respondents indicated that they were not applying the green tourism concept in their operations. On whether the green management of the environment leads to brand awareness, $20 \%$ said no. Said $75 \%$ indicated that they were not aware. On whether green tourism improved brand identify, 45\% indicated that they were not aware, 35\% indicated that it does not improve brand identity. Eighty five percent of the respondents indicated that green management does not have affect in destination image creation. Forty seven percent of the respondents indicated that green management leads to improved perceived quality in image creation. Forty percent indicated that they were not clear about its effects and $13 \%$ indicated that it does not improve the quality in a destination. On whether there is a positive relationship between green tourism and brand loyalty $10 \%$ indicated that there is no relationship. 


\section{Ml Macrothink}

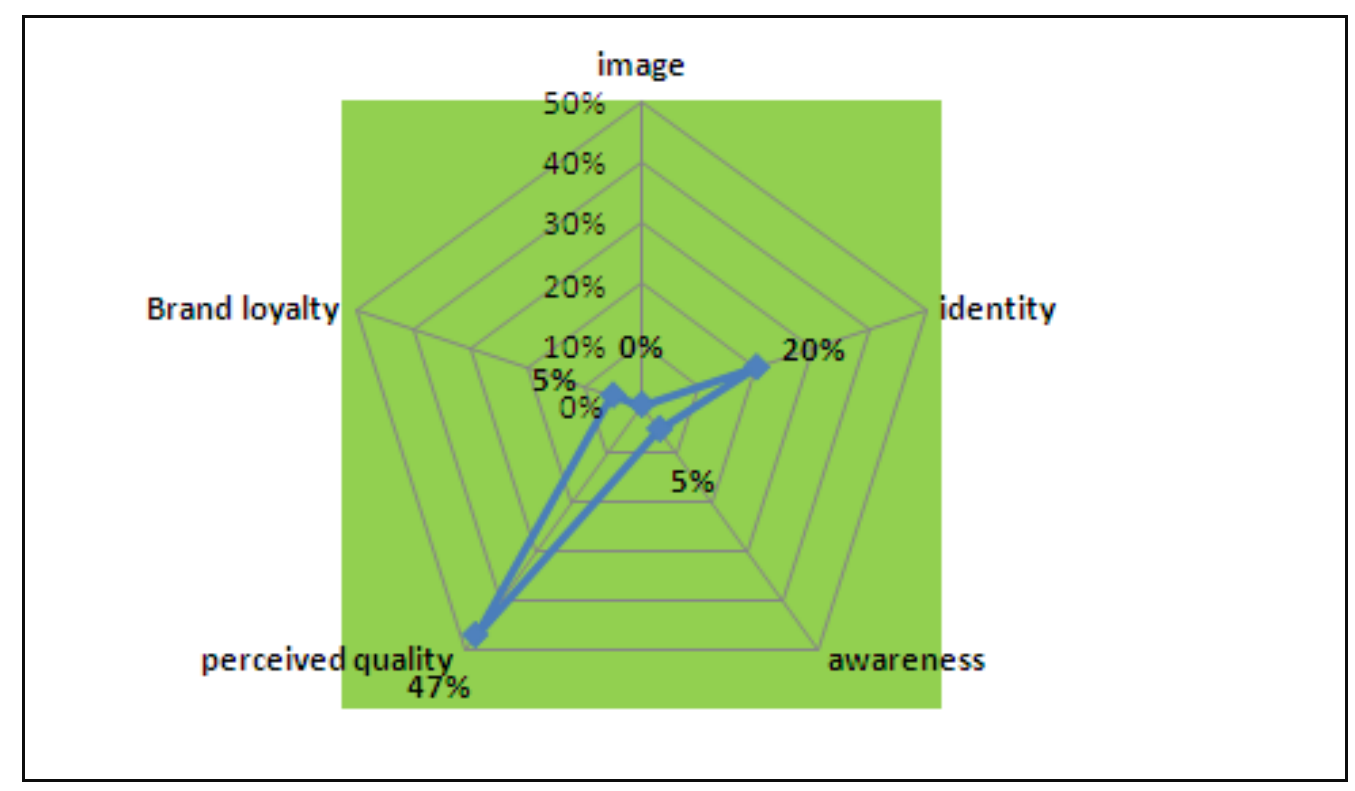

Figure 1.2 Positive responses on environmental effects to brand equity variables: by Management

Source: Research Survey 2015

These few numbers which gave positive respondents were from the managers who seemed to have an appreciation of green management. Five percent of management averred that green management improved brand loyalty, $47 \%$ associated it with quality and 5\% said that it increased brand awareness. Management indicated that the application of green tourism concept in their operations was overdue as it was the new in thing for organisations in this business. Interviews from the senior managers revealed that even the Ministry of Environment, Water and Climate is advocating for a green economy and therefore is an important concept to adopt.

On improving brand identity, most of the mangers indicated that green tourism in deed improve brand identity as international and regional tourists would want to associated with environmentally friendly organisations. Forty seven percent of the managers subscribed to the notion that green management improved the perceived quality of a destination.

\section{Discussion of findings}

The responses from the study as shown in table 1.1 and figure 1.2 shows that the majority $(85 \%)$ from average responses of sectors revealed that they do not agree on the application of green management in tourism. This is in line with Redmond et al., (2008) who suggested that many of the SMEs lack confidence to implement managerial techniques which are not regarded as part of their core business. There is therefore a lack of commitment in environmentally acceptable management techniques in the SME business. Most of those operating in the service sector do not appreciate the benefits of green management (Gadenne, Kennedy, \& McKeiver, 2009, p. 47).Also the respondents showed that only 5\% agreed that green management can result in an improved awareness of the tourism product. Awareness is 
a result of effective branding such that when tourism organisations go green, more tourists will patronise their establishments. The estimated collective impact on SMEs from good environmental practices is highly substantial (Hillary, 2000; a/l Yacob \& Moorthy, 2012). The study also showed that on $5 \%$ of the respondents agreed that brand loyalty can be improved through green tourism. This contradicts with the discovery that environment commitment is an influential instrument in increasing customer loyalty in tourism establishments(Graci \& Kuehnel, 2009, p. 6). However since the Ministry of Environment, Water and Climate are advocating for a green economy, it imperative that all organisations adopt this concept. The assertion by Graci and Dodds (2009)that international tourists are environmentally sensitive is not in agreement with findings of this study. From the findings of this study, it was clear most managers and employees were not clear about the importance of green management in their organisations. This then means that our tourism industry needs to operate according to the best practices otherwise they will lose business to neighbouring countries. Companies that integrate the environment into their business decisions and reduce their environmental risk and potential liabilities are in a better position to improve reputational market exposure

\section{Conclusion}

Green management in sustainable development in the branding of Small to Medium Enterprises (SMEs) in the tourism sector in Zimbabwe is critical even though most of the organisations have not yet adopted it. It is critical that most organisations adopt this approach as it is the in thing in the tourism industry. According to the literature, green management improves brand loyalty, improved image, identity awareness and perceived quality.

\section{Recommendations}

The study recommends that SMEs in the tourism sector should invest more in branding of their businesses and offerings. This highly helps in improving their identity to potential tourists through improved image, brand awareness and perceived quality.

There is need to emphasize and improve on the green management of resources by the SMEs in the tourism sector in Zimbabwe. The green management practice will help in having internal sustainable practices audits and standardization. Therefore for the SMEs to be branded and identified with the green practices they should engage in green certifications. Certified SMEs will have green labels on their products, premises, from office displays, company letterheads, uniform logos and any other areas visible to the current and prospective tourists.

There is need for training in the area of branding to SMEs in the tourism sector. This is because the majority of them lack knowledge and expertise in the use of brands in image building. Managers and employees need to go for regular training in the area of brand management.

Governments can provide crucial support for SMEs to overcome the main barriers for their transition towards the green growth economy and encourage entrepreneurial investment and firm creation in the green markets taking shape. Priorities include initiatives such as: raising SMEs' and entrepreneurs' awareness of the scale and implication of the transition towards a 
green and low carbon economy; tackling SME knowledge and skill gaps in relation to green technologies, practices and business models; and enhancing SME access to the emerging markets of environmental goods and services(BOLOGNA+10, 2010, p. 9).

Access to appropriate types of financing structures and facilities are especially required to allow SMEs and entrepreneurs to respond to the investment needs implied by the transition to a green, low-carbon economy and to take advantage of the opportunities provided by innovation. Enhancing venture capital markets is key to the entry of new firms, particularly high-growth ones, in the emerging green markets (BOLOGNA+10, 2010, p. 9).

Arranging a proper environment for promoting entrepreneurship, especially oriented towards innovative ventures, is essential to accelerate green growth, in light of the evidence that young firms represent a large source of more radical innovations (BOLOGNA+10, 2010, p. $10)$.

\section{Areas for further Studies}

Further studies on establishing branding and green management strategies specifically for SMEs in the tourism sectors which would act as guidelines for improving image are critical.

\section{References}

a/l Yacob, P., \& Moorthy, K. M. (2012). Green Practices: Perception of Malaysian SME Owners/Managers. International Journal of Academic Research in Economics and Management Sciences, 1 (3), 103-111.

ANSA, LEDRIZ and ZCTU (2012) Pro-poor and inclusive development in Zimbabwe: Beyond the Enclave, Weaver Press, Zimbabwe

Bansal, P. and K. Roth: 2000, 'Why Companies Go Green: A Model of Ecological Responsiveness', Academy of Management Journal 43(4), 717-736.

Batta, R.N. (2009). Green tourism certification manual. Tokyo: Asian Productivity Organization (APO).Retrieved April 27, 2010, from http://www.apo-tokyo.org/00e-books/GP-18_GreenTourism.htm\# contents.

Beeton, S., Bergin-Seers, S., \& Christine, L. (2007). ENVIRONMENTALLY SUSTAINABLE PRACTICES OF VICTORIAN TOURISM ENTERPRISES. CRC for Sustainable Tourism, 1-25.

BOLOGNA+10. (2010). SMEs and Green Growth: Promoting Sustainable Manufacturing and Eco-innovation in Small Firms. OECD WPSMEE "BOLOGNA +10" HIGH-LEVEL MEETING ON "SMEs and Entrepreneurship (pp. 3-11). 'BOLOGNA+10'.

Claver-Cortes, E., Molina-Azorin, J.F. Pereira- Moliner, J., Lopez-Gamero, M.D. 2007, 'Environmental Strategies and Their Impact on Hotel Performance' Journal of Sustainable Tourism., vol. 15, no. 6, pp. 663-679. 


\section{Macrothink}

Journal of Entrepreneurship and Business Innovation ISSN 2332-8851

Cordano, M. R., Murray, S., \& Marshall, R. S. (2010). Voluntary sustainability codes can help SMEs go green. Journal of Business Ethics, (92), 463-478.

Erdogan, N. and Tosun, C. (2009). Environmental performance of tourism accommodations in the protected areas: Case of Goreme Historical National Park. International Journal of Hospitality Management. (28), pp. 406-414.

Furqan, A., Mat Som, A. P., \& Hussin, R. (2010). PROMOTING GREEN TOURISM FOR FUTURE SUSTAINABILITY. 64-74.

Hillary, R., (2000), Small and medium sized enterprises and the environment- Business Imperatives, Green Leaf Publishing Ltd, UK.

Honey, M. and Rome, A. (2000). Ecotourism and Sustainable Tourism Certification.New York: Mohonk Mountain House.

Mihalic, T. (2000). Environmental management of a tourist destination: A factor of tourism competitiveness. Tourism Management, 21, pp. 65-78.

Naffziger, D. N. A. and R. Montagno: 2003, 'Perceptions of Environmental Consciousness in US Small Businesses: An Empirical Study', S.A.M. AdvancedManagement Journal 68(2), 23-32.

Perry, P.: 2001, New Millennium may Usher in New Day for ISO 14001, Online Viewed 4 November 2003, http://www.businessstandards.com/content/16ftr3.asp.

Porter, M. and C. van der Linde: 1995, 'Green andCompetitive: Ending the Stalemate', Harvard Business Review 73(5), 120-134.

Redmond, J., Walker, E. A., and Wang C., (2008), Issues for small businesses with waste management, Journal of Environmental Management, 88(2), 275-285.

Revell, A., and Rutherfoord, R., (2003). UK environmental policy and the small firm: Broadening the focus, Business Strategy and Environment, 12, 26-35.

Sasidharan, V., Sirakayab, E. and Kerstettera, D. (2002).Developing countries and tourism ecolabels.Tourism Management. (23), pp. 161-174.

Simpson, M., N. Taylor and K. Barker: 2004, 'Environmental Responsibility in SMEs: Does It Deliver Competitive Advantage?',Business Strategy and theEnvironment 13(3), 156-17.

Tilley, F. J.: 1999, 'Small-Firm Environmental Strategy: The UK Experience', Greener Management International.

Williamson, D. and G. Lynch-Wood: 2001, 'A New Paradigm for SME Environmental Practice', TheTQMMagazine 13(6), 424-432.

Zhang, H.Q., Chong, K. and Ap, J. (1999). An analysis of tourism policy development in modern China.Tourism Management, 20, pp. 471-485. 